\title{
Pierre-Louis Rey, Les existences individuelles de Gobineau
}

Ida Merello

\section{Q OpenEdition}

1 Journals

\section{Edizione digitale}

URL: http://journals.openedition.org/studifrancesi/33503

DOI: 10.4000/studifrancesi.33503

ISSN: 2427-5856

\section{Editore}

Rosenberg \& Sellier

\section{Edizione cartacea}

Data di pubblicazione: 1 décembre 2005

Paginazione: 668

ISSN: 0039-2944

\section{Notizia bibliografica digitale}

Ida Merello, «Pierre-Louis Rey, Les existences individuelles de Gobineau», Studi Francesi [Online], 147 (XLX | III) | 2005, online dal 30 novembre 2015, consultato il 20 avril 2021. URL: http:// journals.openedition.org/studifrancesi/33503 ; DOI: https://doi.org/10.4000/studifrancesi.33503

Questo documento è stato generato automaticamente il 20 avril 2021.

\section{(c) (i) (9)}

Studi Francesi è distribuita con Licenza Creative Commons Attribuzione - Non commerciale - Non opere derivate 4.0 Internazionale. 


\title{
Pierre-Louis Rey, Les existences individuelles de Gobineau
}

\author{
Ida Merello
}

\section{NOTIZIA}

PIERRE-LOUIS REY, Les existences individuelles de Gobineau, «Romantisme», n 124, 2-2004, pp. 115-125.

1 Dopo aver ricordato il costante interesse di Gobineau per l'Oriente e la storia, l'A. mostra però come l'attenzione dominante dello scrittore sia stata comunque riservata alle razze, nonché alle lingue come segno di preminenza o di decadenza di una razza. Si sofferma perciò sul Mémoire sur diverses manifestations de la vie individuelle, scritto in francese e tedesco, in cui Gobineau elabora il mito della lingua perfetta, non ancora degenerata per la commistione delle razze. Ne analizza le diverse componenti, sottolineando il rapporto che Gobineau stabilisce tra lingua pura e razza pura, tra evoluzione linguistica e corruzione dei costumi, attribuendo alla lingua teutonica il carattere di maggiore importanza, come espressione delle alte qualità del popolo tedesco. L'A. mostra la persistenza in Gobineau del sogno del tempo dell'assoluta purezza, corrispondente alla fissità della lingua, nel mito delle lingue dell'origine. L'A. prende in esame quindi la terza parte del Mémoire, in cui lo scrittore, sulla base di argomentazioni poco coese, arriva all'affermazione dell'unicità della sostanza, e della possibile evoluzione individuale verso forme superiori: l'A. mostra come tali riflessioni siano alla base anche del romanzo Pléiades (1874). 